\title{
Distinct pattern of mutations of conserved regions of TP53 in colorectal cancer patients in the Kashmir population: an emerging high-risk area
}

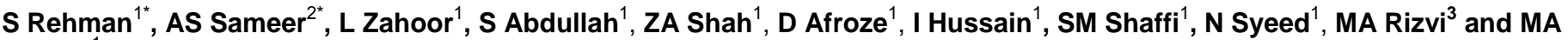 \\ Siddiqi ${ }^{1}$
}

${ }^{1}$ Department of Immunology and Molecular Medicine, Sher-I-Kashmir Institute of Medical Sciences, Soura, Srinagar 190011, Kashmir, India

${ }^{2}$ Department of Clinical Biochemistry, Sher-I-Kashmir Institute of Medical Sciences, Soura, Srinagar 190011, Kashmir, India

${ }^{3}$ Department of Biosciences, Jamia Millia Islamia, New Delhi, India

*First two authors have contributed equally

\section{Abstract}

Background: Colorectal cancer (CRC) is one of the leading causes of mortality and morbidity. The Kashmir valley, in Northern India, has been described as a high-risk area for colorectal cancer.

Aim: The aim was to make a preliminary attempt to study mutations in exons 5-8 (the DNA binding domain) of the tumour suppressor gene TP53 in 42 CRC patients from Kashmir.

Materials and methods: The study population consisted of 42 patients diagnosed with colorectal cancer. Mutations in exons 5-8 of the TP53 gene were detected by means of single-strand conformation polymorphism (SSCP). All samples that showed different band migration patterns in the SSCP were confirmed by sequencing.

Results: The 28 mutations were found in the TP53 gene in 19 patients, comprised 23 substitutions (17 transitions + six transversions), and five insertions. The 23 substitutions represent 18 missense mutations, leading to amino acid substitutions, two nonsense mutations, leading to stop codons, while the remaining three were silent mutations. The five insertions represented frameshifts. Two of 28 mutations (7.14\%) have not been previously reported in colon cancer samples and were identified as novel TP53 mutations. Comparison of the mutation profile with other ethnic populations and regions reflected both differences and similarities indicating co-exposure to a unique set of risk factors.

Conclusions: Mutation of the TP53 gene is one of the commonest genetic changes in the development of human colorectal cancer. The high frequency of TP53 gene mutations implicates TP53 as a predominant factor for colorectal cancer in the high-risk ethnic Kashmir population.

Published: 09/01/2009

Received: 01/11/2008

ecancer 2009, 3:129 DOI: 10.3332/ecancer.2009.129

Copyright: ( $\odot$ the authors; licensee ecancermedicalscience. This is an Open Access article distributed under the terms of the Creative Commons Attribution License (http://creativecommons.org/licenses/by/2.0), which permits unrestricted use, distribution, and reproduction in any medium, provided the original work is properly cited.

Competing Interests: The authors have declared that no competing interests exist.

Correspondence to MA Siddiqi. Email: vc.tmuk@gmail.com 


\section{Introduction}

Colorectal cancer (CRC) is the third most common cause of cancer-related death in the western world. The annual incidence of CRC worldwide has been estimated to be at least half a million [1]. It is a commonly diagnosed cancer in both men and women. In 2008, an estimated 148,810 new cases will be diagnosed, and 49,960 deaths from colorectal cancer will occur [2]. The development of CRC is a multi-step process, which can arise due to the accumulation of mutations in various different oncogenes, tumour suppressor genes and/or from epigenetic changes in DNA [3]. Recent progress made in the field of molecular biology has shed light on the different alternative pathways involved in the colorectal carcinogenesis, and more importantly the crosstalk among these pathways [4,5]. Mutations in the TP53 tumour suppressor gene are identified in approximately $35-45 \%$ of CRC $[6,7,8,9]$, and it may be associated with worse prognosis and chemo/radio resistance $[10,11]$.

TP53 mutations are the most frequently detected genetic alteration in human cancer [12,13]. The TP53 gene is located on the short (p) arm of chromosome 17, and 17p deletions are found in $6-25 \%$ of colonic adenomas and in as many as $75 \%$ of colonic carcinomas $[14,15]$. The TP53 gene encodes a protein, which maintains genomic integrity by inducing cell cycle arrest and apoptosis when DNA is damaged [16]. Mutations in TP53 gene occur in almost half of all CRCs, proposed as a late event in the transition of an adenoma to carcinoma [17]. The mutations in TP53 are thought to cause an increase in the halflife of the protein, and in one study [18] are associated with its' over-expression in the nucleus. Also, most of the mutations in TP53 gene occur in exons 5-8, in highly preserved regions, and in the three main structural domains of the TP53 protein (L2, L3 and the loop-sheet-helix [19]. These mutations cause the synthesis of a stable protein that loses the ability to bind DNA and activation of target genes [20]. Eighty per cent of the alterations that occur in CRC are nonsense mutations: GC to TC transitions occurring in $\mathrm{CpG}$ dinucleotides [21].

The effect that the different alterations located in the different exons on the prognosis of patients with CRC has not been widely studied, although Borrensen-Dale et al showed that the mutations affecting the L3 loop were related with a worse prognosis [19]; nevertheless, other authors have not been able to confirm these conclusions [22]. Other studies suggest that the different mutations in TP53 mat affect the sensitivity of the tumours to treatment.
Therefore, the aim of our study was to assess the contribution of TP53 gene mutations in incidence and development of colorectal cancer in patients from the Kashmir valley, since such data from this region are not available in the literature. Furthermore, we compared the mutation pattern in TP53 from the present study with the International Agency for Research on Cancer (IARC) TP53 database, as well as the data reported from various regions to dissect out the differences and similarities in the mutation profile.

\section{Materials and methods}

\section{Patient specimens}

From 56 patients who were diagnosed with CRC by clinicians using sigmoidoscopy and colonoscopy, tissue specimens from 42 colorectal cancers were obtained with consent from patients who underwent curative surgical resection from January 2005 to 2007 at the Department of General Surgery, Sher-I-Kashmir Institute of Medical Sciences, Srinagar, India. An experienced pathologist selected a representative tumour block and surrounding normal mucosal tissue block for each case. The patient group included 13 women and 29 men with ages ranging from 55 to 82 years. Overall, 22 tumours were localized in the colon and 20 in the rectum. Clinical diagnosis was confirmed in all cases by histological examination. The study protocol was approved by the Research Ethics Committee of the Sher-IKashmir Institute of Medical Sciences.

\section{DNA isolation}

Genomic DNA was extracted from single-cell suspension of blood and tissue samples of colorectal cancer patients by standard Proteinase-K digestion and phenol/chloroform extraction for examining mutations in TP53 [23].

\section{PCR-SSCP analysis}

Exons 5-8 of the TP53 gene encoding the DNA binding domain were amplified using four specific oligonucleotide primers (Table 1). PCR was performed in a $25-\mu l$ total volume reaction mixture containing $50 \mathrm{ng}$ of genomic DNA, $100 \mathrm{ng}$ of each primer, 100 $\mu \mathrm{M}$ of each NTP, $1.5 \mathrm{mM} \mathrm{MgCl}_{2}, 1 \mathrm{X}$ of Taq buffer and 0.1 unit of Taq DNA polymerase (Fermentas). PCR was performed 
Table 1: Primers used for screening different exons of TP53

\begin{tabular}{|c|c|c|l|c}
\hline \multicolumn{5}{|c}{} \\
\hline Gene & Amplicon & $\begin{array}{c}\text { Nucleotide position in } \\
\text { genomic DNA }\end{array}$ & \multicolumn{1}{c}{ Primer sequence } & $\begin{array}{c}\text { Annealing } \\
\text { temperature }\end{array}$ \\
\hline TP53 & Exon 5 & $\begin{array}{l}13005-13024 \\
13295-13314\end{array}$ & $\begin{array}{l}\text { F: TGTTCACTTGTGCCCTGACT } \\
\text { R: AGCAATCAGTGAGGAATCAG }\end{array}$ & 55 \\
\hline TP53 & Exon 6 & $13271-13280$ & F: TGGTTGCCCAGGGTCCCCAG & 62 \\
& & $13475-13494$ & R: TGGAGGGCCACTGACAACCA & \\
\hline TP53 & Exon 7 & $13941-13960$ & F: CTTGCCACAGGTCTCCCCAA & 62 \\
& & $14158-14177$ & R: AGGGGTCAGCGGCAAGCAGA & \\
\hline TP53 & Exon 8 & $14442-14461$ & F: TCCTGAGTAGTGGTAATCTA & 58 \\
& & $14579-14598$ & R: GCTTGCTTACCTCGCTTAGT & \\
\hline
\end{tabular}

F: Sense primer; R: antisense primer.

using the following conditions: initial denaturation at $95^{\circ} \mathrm{C}$ for two minutes, 35 cycles of denaturation at $95^{\circ} \mathrm{C}$, annealing at 52-62 ${ }^{\circ} \mathrm{C}$ (see Table 1) and extension at $72^{\circ} \mathrm{C}$ for one minute each and final extension at $72^{\circ} \mathrm{C}$ for 5 minutes in Biorad cycler. Negative controls (DNA was replaced with water) were amplified by PCR and included in each experiment. The PCR products were separated on a $2 \%$ agarose gel and analysed under a UV illuminator.

The SSCP analysis of the amplicons of exons 5-8 was performed on $6 \%$ non-denaturing polyacrylamide gels (PAGE), utilizing either non-radioactive silver staining or radioactive procedures [24,25]. For non-radioactive SSCP analysis [26], PCR products in denaturing buffer (95\% formamide, $10-\mathrm{mM}$ $\mathrm{NaOH}, 0.05 \%$ xylene-cyanol FF and $0.05 \%$ bromophenol blue) in $1: 1$ ratio were heat denatured at $95^{\circ} \mathrm{C}$ for five minutes, immediately cooled on ice for 20 minutes and $6 \mu$ of each was loaded onto a $6 \%$ PAGE and electrophoresed in $0.5 \mathrm{X}$ Trisborate EDTA buffer at $\pm 17^{\circ} \mathrm{C}$ at $4 \mathrm{~W}$ constant power for 18-22 hours. Gels were then silver stained. For radioactive SSCP analysis, radio-labelled PCR products (using a32-pCTP) were added to denaturing buffer (95\% formamide, $20 \mathrm{mM}$ EDTA, $0.05 \%$ xylene-cyanol FF and $0.05 \%$ bromophenolblue) in a $1: 10$ ratio and were heat denatured at $95^{\circ} \mathrm{C}$ for 5 minutes, $3 \mu$ of which were loaded on $6 \%$ PAGE and electrophoresed at $4 \mathrm{~W}$ in $0.5 \mathrm{X}$ Tris-borate EDTA buffer at $\pm 17^{\circ} \mathrm{C}$ for $18-22$ hours. PCRSSCP analysis was repeated twice for each sample to minimize the possibility of artefacts due to contamination or polymerase errors. Interpretation of the SSCP analysis was by the consensus of two investigators. The gel was then transferred onto $3 \mathrm{~mm}$ Whatmann paper, covered with Saran wrap and dried in a vacuum drier at $90^{\circ} \mathrm{C}$ for one hour. The Saran wrap was then replaced by $\mathrm{x}$-ray film and kept at $-70^{\circ} \mathrm{C}$ for 48 hours. The mobility shift in DNA bands were visualized by developing the x-ray film in a developer.

\section{Sequencing}

Purified PCR products of the samples showing mobility shift on SSCP analysis and randomly chosen normal samples were used for direct DNA sequencing, using the automated 'ABI prism 310'. To minimize the sequencing artefacts by PCR, products from at least two different PCRs were sequenced using forward and reverse primers with BigDye terminator cycle sequencing ready reaction mix (Applied Biosystems) based on fluorescence-labelled dideoxy nucleotides as chain terminators. Purified single-stranded extension products were then resolved on the $A B I$ Prism 310 sequencer.

\section{Statistics}

All statistical analysis was performed using SPSS software, version 12 (SPSS, Chicago, IL). The chi-square test was used to determine associations of the presence of TP53 with various clinicopathological parameters and classical risk factors such as smoking habit. Statistical significance was considered when $\mathrm{p} \leq 0.05$.

\section{Results}

Forty-two CRC cases were analysed for TP53 gene mutation (exon $5-8$ ) by PCR-SSCP followed by sequencing. Analysis of these genetic alterations revealed 28 mutations in 19 of 42 cases analyzed (45\%) (Table 2). Among these there were five frameshift mutations, 17 transitions and six transversions. Frameshift mutations were observed at codon 264 (exon 8), 304 (exon 8), 297(exon 8), 166 (exon 5) and 174 (exon 5), respectively. There were three silent mutations at codon 154 (exon 5), 222 (exon 6), 224 (exon 6) and two nonsense mutations at codon 196 (exon 6) and 192 (exon 6), respectively. 
Table 2: Details and nature of TP53 mutations in colorectal cancer patients from Kashmir valley

\begin{tabular}{|c|c|c|c|c|c|c|c|c|c|c|c|c|c|}
\hline $\begin{array}{c}\text { PATIENT } \\
\text { ID }\end{array}$ & $\begin{array}{l}\text { AGE I } \\
\text { SEX }\end{array}$ & $\begin{array}{l}\text { RURAL / } \\
\text { URBAN }^{\text {b }}\end{array}$ & $\begin{array}{l}\text { DUKE'S } \\
\text { STAGE }^{\circ}\end{array}$ & $\begin{array}{l}\text { SMOKING } \\
\text { STATUUS }^{d}\end{array}$ & GRADE & SITE ${ }^{f}$ & TYPE $^{9}$ & NATURE & EXON & $\begin{array}{c}\text { CODON } \\
\text { NUMBER }\end{array}$ & $\begin{array}{c}\text { BASE } \\
\text { CHANGE }\end{array}$ & $\begin{array}{l}\text { AMINOACID } \\
\text { CHANGE }\end{array}$ & EFFECT \\
\hline $1 \mathrm{C}$ & $55 / \mathrm{M}$ & $\mathrm{R}$ & C & NSk & III & C & $A C$ & FAP & 5 & 175 & $C G C>I G C$ & Arg > Cys & MS \\
\hline \multirow[t]{2}{*}{$2 \mathrm{C}$} & \multirow[t]{2}{*}{$72 / M$} & \multirow[t]{2}{*}{$\mathrm{R}$} & \multirow[t]{2}{*}{$\mathrm{D}$} & \multirow[t]{2}{*}{ NSk } & \multirow[t]{2}{*}{ III } & \multirow[t]{2}{*}{$\mathrm{R}$} & \multirow[t]{2}{*}{$A C$} & \multirow[t]{2}{*}{$S$} & 5 & 154 & $G G C>G G I$ & Gly > Gly & MS \\
\hline & & & & & & & & & 7 & 248 & $C G G>I G G$ & $\operatorname{Arg}>\operatorname{Trp}$ & MS \\
\hline \multirow[t]{2}{*}{$5 \mathrm{C}$} & \multirow[t]{2}{*}{$68 / \mathrm{F}$} & \multirow[t]{2}{*}{ U } & \multirow[t]{2}{*}{ D } & \multirow[t]{2}{*}{ NSk } & \multirow[t]{2}{*}{ ॥ } & \multirow[t]{2}{*}{$\mathrm{R}$} & \multirow[t]{2}{*}{ AC } & \multirow[t]{2}{*}{ s } & 7 & 248 & $\mathrm{CGG}>\underline{I G G}$ & $\operatorname{Arg}>\operatorname{Trp}$ & MS \\
\hline & & & & & & & & & 8 & 265 & $\mathrm{CTG}>\mathrm{C} \underline{\mathrm{C}} \mathrm{G}$ & Leu $>$ Pro & MS \\
\hline $8 \mathrm{C}$ & $62 / F$ & $\mathrm{R}$ & C & Sk & 1 & C & M & $s$ & 6 & 221 & $\mathrm{GAG}>\mathrm{GA} \underline{\mathrm{C}}$ & Glu $>$ Asp & MS \\
\hline $11 \mathrm{C}$ & $45 / \mathrm{M}$ & $\mathrm{R}$ & D & Sk & III & $\mathrm{R}$ & $\mathrm{AC}$ & $s$ & 6 & 196 & $C G A>C A A$ & Arg $>$ Stop & TP \\
\hline \multirow[t]{2}{*}{$14 \mathrm{C}$} & \multirow[t]{2}{*}{$82 / F$} & \multirow[t]{2}{*}{ U } & \multirow[t]{2}{*}{ C } & \multirow[t]{2}{*}{ Sk } & \multirow[t]{2}{*}{ II } & \multirow[t]{2}{*}{$\mathrm{R}$} & \multirow[t]{2}{*}{$A C$} & \multirow[t]{2}{*}{$\mathrm{s}$} & 6 & 222 & $\mathrm{CCG}>\mathrm{CC} \underline{\mathrm{C}}$ & Pro $>$ Pro & MS \\
\hline & & & & & & & & & 8 & 264 & CTA $>$ ICTA & Leu $\gg \gg \gg$ & FS \\
\hline \multirow[t]{2}{*}{$16 \mathrm{C}$} & $51 / \mathrm{M}$ & u & C & Sk & II & c & $A C$ & s & 5 & 181 & $C G C>\underline{I G C}$ & Arg $>$ Cys & MS \\
\hline & & & & & & & & & 6 & 193 & CAT > CE $\underline{G}$ & His $>$ Arg & MS \\
\hline $19 \mathrm{C}$ & $67 / \mathrm{M}$ & $\mathrm{R}$ & D & NSk & III & $\mathrm{R}$ & $A C$ & $\mathrm{~s}$ & 8 & 282 & $\mathrm{CGG}>\mathrm{T} \underline{\mathrm{G}} \mathrm{G}$ & $\operatorname{Arg}>\operatorname{Trp}$ & MS \\
\hline $21 \mathrm{C}$ & $66 / F$ & $\mathrm{R}$ & $\mathrm{C}$ & NSk & II & $\mathrm{R}$ & $\mathrm{AC}$ & $\mathrm{s}$ & 7 & 245 & $G G C>\underline{A} G C$ & Gly $>$ Ser & MS \\
\hline $22 \mathrm{C}$ & $77 / \mathrm{M}$ & u & B & NSk & 1 & $\mathrm{R}$ & $A C$ & s & 6 & 202 & $\mathrm{CGT}>\mathrm{C} \underline{\mathrm{IT}}$ & Arg $>$ Leu & MS \\
\hline & & & & & & & & & 8 & 272 & $\mathrm{GTG}>\underline{\mathrm{A} T \mathrm{TG}}$ & $\mathrm{Val}>\mathrm{Met}$ & MS \\
\hline $27 \mathrm{C}$ & $69 / \mathrm{M}$ & $\mathrm{R}$ & C & Sk & III & $\mathrm{R}$ & $A C$ & $\mathrm{~s}$ & 5 & 177 & $\mathrm{CCC}>\mathrm{C} \underline{\mathrm{IC}}$ & Pro $>$ Leu & MS \\
\hline & & & & & & & & & 8 & 304 & $\mathrm{ACT}>$ IACT & 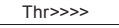 & FS \\
\hline $28 \mathrm{C}$ & $42 / \mathrm{M}$ & u & $\mathrm{C}$ & Sk & II & $\mathrm{R}$ & $\mathrm{M}$ & $\mathrm{s}$ & 8 & 261 & $A G T>A G \underline{G}$ & Ser $>$ Arg & MS \\
\hline $31 \mathrm{C}$ & $64 / \mathrm{M}$ & $\mathrm{R}$ & C & Sk & ॥ & C & $A C$ & HNPCC & 6 & 224 & $G A G>G A \underline{A}$ & Glu $>$ Glu & MS \\
\hline & & & & & & & & & 8 & 297 & $C A C>C I A C$ & His $\gg \gg>$ & FS \\
\hline $33 \mathrm{C}$ & $71 / \mathrm{M}$ & $\mathrm{R}$ & D & Sk & III & $\mathrm{R}$ & $A C$ & $s$ & 5 & 171 & $\mathrm{GAC}>\underline{\mathrm{C}} \mathrm{AG}$ & Glu > Gln & MS \\
\hline & & & & & & & & & 5 & 174 & $A G G>A G \underline{A G}$ & $\operatorname{Arg} \gg \gg \gg$ & FS \\
\hline $36 \mathrm{C}$ & $68 / \mathrm{M}$ & $\mathrm{R}$ & $\mathrm{C}$ & Sk & II & $\mathrm{R}$ & $\mathrm{AC}$ & $\mathrm{s}$ & 6 & 192 & $C A G>\underline{I} A G$ & $\operatorname{Arg}>$ Stop & TP \\
\hline $37 \mathrm{C}$ & $60 / \mathrm{F}$ & u & A & NSk & III & $\mathrm{R}$ & $A C$ & $\mathrm{~s}$ & 5 & 155 & $A C C>\underline{G} C C$ & $\mathrm{Thr}>\mathrm{Ala}$ & MS \\
\hline $39 \mathrm{C}$ & $75 / \mathrm{M}$ & u & D & Sk & III & $\mathrm{R}$ & $A C$ & $\mathrm{~s}$ & 7 & 248 & $\mathrm{CGG}>\mathrm{CA} \underline{\mathrm{G}}$ & $\operatorname{Arg}>\mathrm{Gln}$ & MS \\
\hline $41 \mathrm{C}$ & $72 / \mathrm{M}$ & $\mathrm{R}$ & C & Sk & II & $\mathrm{R}$ & $A C$ & $\mathrm{~s}$ & 5 & 157 & GTC $>\underline{I T C}$ & Val > Pro & MS \\
\hline $42 \mathrm{C}$ & $70 / \mathrm{F}$ & $\mathrm{R}$ & c & Sk & III & $\mathrm{R}$ & $A C$ & $\mathrm{~s}$ & 5 & 166 & TCA $>\underline{\text { ATCA }}$ & Ser»»»> & FS \\
\hline & & & & & & & & & 5 & 175 & $C G C>C A C$ & $\operatorname{Arg}>\mathrm{His}$ & MS \\
\hline
\end{tabular}

age/sex: $\mathrm{M}=$ male, $\mathrm{F}=$ Female.

${ }^{b}$ Rural/urban: $R$ = rural, $U=$ urban.

'Dukes' stage: $\mathrm{A}=$ Tumour confined to the intestinal wall; $\mathrm{B}=$ tumour invading through the intestinal wall; $\mathrm{C}=$ with lymph node(s) involvement; $\mathrm{D}=$ with distant metastasis.

dSmoking status: $\mathrm{Sk}=$ Smokers; $\mathrm{NSk}=$ non-smokers

éGrade stage: Stage I = T1/T2,N0,M0; Stage II = T3/T4,N0,M0; Stage III = any, N1/N2,M0; Stage IV = AnyT, AnyN,M1.

fSite of tumour: $\mathrm{C}=$ Colon, $\mathrm{R}=$ rectum

9Tumour type: $\mathrm{AC}=$ Adenocarcinoma; $\mathrm{M}=$ mucoid

hNature of tumour: $\mathrm{S}=$ Sporadic; $\mathrm{FAP}=$ familial adenomatous polyposis; HNPCC = hereditary non-polyposis colorectal cancer

'Base change: Mutated or inserted nucleotide underlined: + = mutation at CpG site.

'Effect: MS = Missense; FS = frameshift; TP = truncated protein.

Analysis of the mutation spectrum revealed a number of salient and interesting features, which included high frequency of $G: C$ to $A: T$ substitutions. Among the 28 mutations, there were ten in exon 5 , seven in exon 6 , four in exon 7 and seven in exon 8. Mutations at codon 248 were detected in three cases, while mutations at codon 175 were detected in two cases (Table 4). Our results are consistent with previous reports on the prevalence of TP53 mutations in CRC ranging from $42 \%$ to $67 \%$ in other parts of the world. Mutation effect data revealed a high percentage of missense mutations (23/28) (82.14\%) compared to frameshift mutations (5/28) $(17.85 \%)$. Also, mutation pattern data of TP53 revealed a high percentage of $\mathrm{G}: \mathrm{C}>\mathrm{A}: \mathrm{T}$ (at $\mathrm{CpG}$ + non-CpG sites) (12/28) (42.85\%) and $\mathrm{G}: \mathrm{C}>\mathrm{C}: \mathrm{G}(3 / 28)$ $(10.71 \%)$, transition and transversion mutations, respectively. All the missense mutations occurred in heterozygous state except one at codon 221, which occurred in homozygous state.
A significant amount of mutations were found in exon $5(35.7 \%)$ exon $6(25 \%)$, exon $7(14.28 \%)$ and exon 8 (25\%), respectively. Twenty-eight per cent (8/28) of the TP53 mutations were located at hotspot codons 175, 196, 245, 248 and 282, but no mutations were detected at the hotspot codon 273. A nonsense mutation at codon 196 never reported in colorectal cancer (Arg $>$ Stop) was found in one tumour.

Taking into account classical risk factors and clinicopathological parameters on the presence of TP53 mutations, there was a statistically significant increase $(p=0.01 ; \quad O R=6.17 ; 95 \%$ $\mathrm{Cl}=1.58-24.05)$ in the incidence of $T P 53$ mutations in smokers rather than non-smokers. A significantly higher frequency of TP53 mutations was seen in rectal $(75 \%)$ compared with colon $(18.1 \%)$ cancers $(p=0.01 ;$ OR=0.29; 95\% Cl=0.07-1.14). The study also showed a statistically significant increase $(p=0.0001$; 
Table 3: Association of TP53 gene mutation with clinico-epidemiological features of 19 mutant colorectal cancer patients

\begin{tabular}{|c|c|c|c|}
\hline Variable & $\mathbf{N}(\%)$ & P value & OR $(95 \% \mathrm{CI})$ \\
\hline Sex & $\begin{array}{l}\text { Males: } 13 / 29(44.8) \\
\text { Females: } 6 / 13(46.2)\end{array}$ & 1.00 & $0.947(0.254-3.524)$ \\
\hline Age & $\begin{array}{l}\leq 65: 7 / 17(41.2) \\
>65: 12 / 25(48.0)\end{array}$ & 0.75 & $0.758(0.21-2.63)$ \\
\hline Dwelling & $\begin{array}{l}\text { Rural: } 12 / 23(52.2) \\
\text { Urban: } 7 / 19(36.8)\end{array}$ & 0.36 & $1.87(0.54-6.46)$ \\
\hline Smoking Status & $\begin{array}{l}\text { Smokers: } 12 / 17(70.5) \\
\text { Non Smokers: } 7 / 25(28)\end{array}$ & 0.01 & $6.17(1.58-24.05)$ \\
\hline Nature & $\begin{array}{l}\text { S: } 17 / 34(50.0) \\
\text { FAP: } 1 / 6(16.7) \\
\text { HPNCC:1/2(50.0) }\end{array}$ & $\begin{array}{l}0.196 \\
1.00 \\
0.99\end{array}$ & $\begin{array}{l}5.0(0.52-47.43) \\
1.0(0.05-17.32) \\
0.2(0.006-6.664)\end{array}$ \\
\hline Dukes Stage & $\begin{array}{l}\text { A+B: } 2 / 20(10 \%) \\
\text { C+D: } 17 / 22(77.27 \%)\end{array}$ & 0.0001 & $0.03(0.005-.19)$ \\
\hline $\begin{array}{l}\text { Differentiation } \\
\text { Grade }\end{array}$ & $\begin{array}{l}\text { I: } 2 / 18(11.11 \%) \\
\text { II+III: } 17 / 24(70.83 \%)\end{array}$ & 0.0001 & $0.05(.0092-.285)$ \\
\hline Site & $\begin{array}{l}\text { Colon: } 4 / 22(18.1 \%) \\
\text { Rectum: } 15 / 20(75 \%)\end{array}$ & 0.01 & $0.29(0.07-1.14)$ \\
\hline Colon Site & $\begin{array}{l}\text { Proximal: } 1 / 4(25.0) \\
\text { Distal: } 3 / 5(75.0)\end{array}$ & 0.52 & $0.22(0.012-3.97)$ \\
\hline Histological Type & $\begin{array}{l}\text { AC: } 17 / 36(47.2) \\
\text { Mucoid: } 2 / 6(33.3)\end{array}$ & 0.67 & $1.78(0.29-11.03)$ \\
\hline
\end{tabular}

OR=0.03; 95\% Cl=0.005-0.19) in the incidence of TP53 mutations in Dukes' Stage $C$ and $D$ when compared with $A$ and B. The comparison did not show significant association with age, sex or dwelling (Table 3 ). In addition, by taking into account the specific functional and structural domains of TP53 affected by the mutations, the cases were also classified as follows: four of 19 cases (21\%) with mutations of the L3 loop; one of 19 cases $(5.2 \%)$ with mutations of the LSH motif; and 14 of 19 cases $(73.6 \%)$ with mutations outside L3 loop and LSH.

\section{Discussion}

Mutations of TP53 are found in approximately half of all CRC cases, with a higher frequency observed in distal colon and rectal tumours, and a lower frequency in proximal, mucinous and $\mathrm{MSI}+$ tumours. Previous analyses on different types of tumours have shown that most of the TP53 mutations ( 95\%) affect exons 5-8, which code for residues 130-286, the most important region for the folding and, therefore, for the stabilization of the tertiary structure of the protein (core domain), and which contains the site-specific DNA-binding domain [28]. In our screen for mutations in exons 5-8 of TP53 on genomic DNA from primary CRCs of 42 patients, we observed a mutation frequency of $45.2 \%$ (19 of 42 ), within the fairly wide range of values reported previously in CRC (23-61\%) [29-34]. This variability may be the result of the different methods used to assess TP53 mutations (SSCP, denaturing gradient gel electrophoresis, temperature gradient gel electrophoresis and direct sequencing), the type of tumour storage (fresh/frozen tissue and paraffin embedded blocks), an intrinsic tumoural heterogeneity, and, in addition, more specific features of the patient cohorts in the study, in particular, histopathological staging and grading of the tumour. In fact, patients at an advanced Dukes' stage (C and D) and/or with poorly differentiated tumours (G3) generally present a higher rate of TP53 mutations [34,35], which correlates with our study. In accordance with several other reports [29, 32, 34], 46.4\% of all of the mutations observed in our series (13 of 28) were in four of the five highly conserved areas of the gene, which include two important regions for TP53 binding to DNA. One of these contains the amino acids needed for DNA interaction, in particular those that are part of the $\mathrm{L} 3 \mathrm{Zn}-\mathrm{BD}$ and of the $\mathrm{LSH}$ motif. In our own series, $14.2 \%$ (4 of 28 ) of the mutations occurred in L3 and 3.5\% (1 of 28) in LSH, in accordance with the results reported by Borresen-Dale et al [36]. Our data confirm that arginines 248 and 273, which interact directly with DNA, are among the most frequently mutated residues (in our series: $10 \%$ and $0 \%$, respectively). The second region, which when mutated results in loss of TP53 DNA-binding capacity 
Table 4: Mutation profile of the 19 colorectal carcinoma patients

\begin{tabular}{|l|l:l:l} 
& $\mathbf{N}$ & $\%$ & IARC (\%) \\
\hline Samples: & $\mathbf{4 2}$ & & \\
Wild Type & 23 & 54.8 & \\
Mutant & 19 & 45.2 & 43.6 \\
\hline Mutation Type: & & & \\
Missense & 18 & 64 & 72.8 \\
Nonsense & 2 & 7.1 & 7.9 \\
Frameshift & 5 & 17.8 & 12.1 \\
Silent & 3 & 10.7 & 4.24 \\
\hline Substitutions: & 1 & 3.5 & 2.81 \\
A:T>C:G & 3 & 10.7 & 8.92 \\
A:T>G:C & 0 & 0 & 3.75 \\
A:T>T:A & 12 & 42.85 & 14.5 \\
G:C>A:T & 3 & 10.7 & 7.51 \\
G:C>C:G & 4 & 14.28 & 8.92 \\
G:C>T:A & 10 & 35.7 & 33 \\
\hline Exon mutation distribution: & & \\
Exon 5 & 7 & 25 & 8 \\
Exon 6 & 4 & 14.3 & 29 \\
Exon 7 & 7 & 25 & 5 \\
Exon 8 & & & \\
\hline Hotspot Codon Mutations: & 2 & 7.1 & 14 \\
175 & 1 & 3.5 & 6 \\
245 & 3 & 10.7 & 13 \\
248 & 0 & 0 & 7.5 \\
273 & 1 & 3.5 & 6 \\
282 & & &
\end{tabular}

includes the amino acids located in $L 2$, which are required for the folding and stabilization of the central domain [28]. Mutations in this area were observed more frequently in our own series $(28.5 \%)$. Mutations at specific codons, such as codon 175, may be an indication of specific exposures to toxic agents or of genomic susceptibility. It has been observed, however, that mutations in codon 175 are more frequent in the colon than in the rectum, as previously described by Servomaa et al [37], correlating with our study. A peculiarity of the TP53 mutations in Kashmiri CRC tumours was the lack of deletions $(0 \%$ versus $6.57 \%$ in IARC) and a higher prevalence of insertions $17.85 \%$ versus $1.4 \%$ in IARC R12, release). In our study, $\mathrm{G}: \mathrm{C} \rightarrow \mathrm{A}: \mathrm{T}$ mutations were more frequent in the $\mathrm{CpG}$ sites $(32.14 \%)$ then non-CpG sites $(21.42 \%)$, nearly matching what was reported in the study from Delhi, India (unpublished data, personal communication). The high prevalence of $G: C \rightarrow A: T$ mutations was again an observation of interest in our study. However, to establish a correlation between the enhanced $\mathrm{G} \rightarrow \mathrm{A}$ transition $(53.56 \%$ ) and the presence of nitrosamines in foodstuffs consumed in Kashmir [38] needs further investigation. Alkyl nitrosamines can cause $\mathrm{O}^{6}$-alkyl guanine adducts and base misrepairing during replication, resulting in
$\mathrm{G} \rightarrow \mathrm{A}$ (or $\mathrm{C} \rightarrow \mathrm{T}$ on the other strand of the DNA) transition [39] and are considered a major risk factor for the Chinese. $\mathrm{G}: \mathrm{C} \rightarrow \mathrm{C}: \mathrm{G}$ transition was comparatively high in Kashmiri samples $(14.28 \%$ ) versus $7.51 \%$ in IARC). The $\mathrm{G}: \mathrm{C} \rightarrow \mathrm{T}: \mathrm{A}$ transversion was observed to be confined to males who smoke. This type of mutation has been suggested to arise as a result of adducts formation at guanosine by metabolites of benzo(a)pyrene 7,8-diol-9,10-epoxide, a major tobacco carcinogen [40]. Interestingly, in our study, we found $35 \%$ of mutations occurred at the hotspot codons in rectal tumours as opposed to $17 \%$ in colon tumours, which is contrary to a collaborative study on CRC in which the frequency is $34 \%$ and $41 \%$, respectively [41]. In addition, in our series, the frequency of transition and transversion mutations in rectal tumours was $59 \%$ and $23 \%$, respectively, while in colon tumours was $67 \%$ and $17 \%$, respectively, again contrary to a collaborative study on CRC in which there is no difference in the frequency of transition and transversion mutations between rectal and colon tumours [41]. The reasons for the comparably high frequency of transition mutations in colon tumours, and the high frequency of transversions in rectal tumours needs further investigation. 

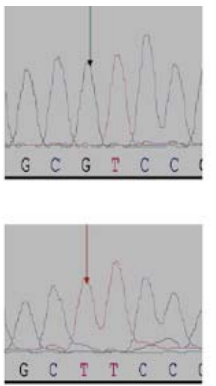

Ex5 GTC $>$ TTC
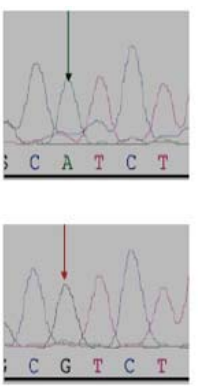

Ex6 CAT $>$ CGT
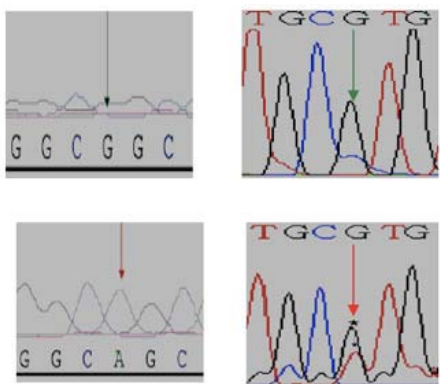

Ex7 GGC > AGC

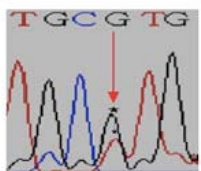

Ex6 CGT > CTT

Figure 1: Partial electropherograms representing the normal $(A)$ and mutant (B) (shown by asterisk and arrows), profiles in $A$ of exon 5 , in $B$ of exon 6, in $C$ of exon 7 and in D of exon 8 of TP53. 1A shows the transversion of $G$ to T. 1B shows the transition of $A$ to $G$. 1C shows the transition of $G$ to $A$. 1D shows the transversion of $G$ to $T$.

In summary, a significantly higher frequency of TP53 mutations was seen in rectal $(75 \%)$ compared with colon $(18.1 \%)$ cancers $(p=0.01 ; O R=0.29 ; 95 \% \mathrm{Cl}=0.07-1.14)$. The reasons for this are unknown but may indicate a more important role for TP53 mutation in the development of rectal compared with colon tumours. Also, significantly higher frequencies of TP53 mutations were seen in smokers rather than non-smokers. Interestingly, $70.58 \%(12 / 17)$ of patients who smoke had mutations in TP53 $(p=0.01)$ compared to only $28 \%(7 / 25)$ of non-smokers. For each site, the more advanced Dukes' C-D tumours contained higher frequencies of TP53 mutations compared with Dukes' A-B tumours (Table 3). The higher frequency of TP53 mutations in Dukes' C-D (77.27\%) compared with Dukes' A-B (10\%) tumours suggests these mutations are associated with a more aggressive phenotype. In support of this, tumours with the poor prognostic features, that is vascular or lymphatic invasion, also showed significantly higher frequencies of TP53 mutations in the overall CRC cohort [42].

To sum up, the high frequency of delirious nonsense, frameshift and missense mutations observed in the TP53 gene in tumours of patients with clinicopathological features such as Dukes' C-D and histopathogical grade II and III is a finding that assumes significance in view of the fact that these features reflect poor prognosis. The study, therefore, suggests TP53 as a potential molecular marker and prognostic tool, at least in a subset of colorectal tumours. Nevertheless, these observations need further investigation on a larger cross section of the colorectal cancer patients with relevant controls. 


\section{References}

1. Kemp Z, Thirlwell Z, Sieber O, Silver A and Tomlinson I (2004) An update on the genetics of colorectal cancer Hum Mol Genet 132 R177-R185 doi: 10.1093/hmg/ ddh247

2. American Cancer Society (2008) Cancer Facts and Figures (Atlanta, Ga: American Cancer Society)

3. Akkiprik M, Ataizi-Celikel C, Düşünceli F et al (2007) Clinical Significance of p53, K-ras and DCC Gene Alterations in the Stage I-II Colorectal Cancers J Gastrointestinal Liver Dis 16 111-7 PMID 17410283

4. Risques RA, Moreno V, Rias M et al (2003) Genetic pathways and genome wide determinants of clinical outcome in colorectal cancer Cancer Res 63 7206-14 PMID: 14612515

5. Takayama $T$, Miyanishi $K$, Hayashi $T$, Sato $Y$ and Niitsu $Y$ (2006) Colorectal cancer: genetics of development and metastasis J Gastroenterol 41 185-92 PMID: 16699851 doi: $10.1007 / \mathrm{s} 00535-006-1801-6$

6. Samowitz WS, Curtin K, Ma KN et al (2002) Prognostic significance of p53 mutations in colon cancer at the population level Int $\boldsymbol{J}$ Cancer 99 597-602 PMID: 11992552 doi: $10.1002 /$ ijc. 10405

7. Tortola S, Marcuello E, Gonzalez I et al (1999) p53 and Kras gene mutations correlate with tumour aggressiveness but are not of routine prognostic value in colorectal cancer J Clin Oncol 17 1375-81 PMID: 10334521

8. Hernandez-Boussard T, Rodriguez-Tome P, Montesano R and Hainaut P (1999) IARC p53 mutation database: a relational database to compile and analyze p53 mutations in human tumours and cell lines. International Agency for Research on Cancer Hum Mutat 14 1-8 PMID: 10447253 doi: 10.1002/(SICl)10981004(1999)14:1<1::AID-HUMU1>3.0.CO;2-H

9. Soong R, Powell B, Elsaleh $\mathrm{H}$ et al (2000) Prognostic significance of TP53 gene mutation in 995 cases of colorectal carcinoma. Influence of tumour site, stage, adjuvant chemotherapy and type of mutation Eur $\mathbf{J}$ Cancer 36 2053-60 PMID: 11044641 doi: 10.1016/S09598049(00)00285-9

10. Lowe SW, Schmitt EM, Smith SW, Osborne BA and Jacks $T$ (1993) p53 is required for radiation-induced apoptosis in mouse thymocytes Nature 362 847-9 PMID: 8479522 doi: 10.1038/362847a0

11. Lowe SW, Bodis S, McClatchey A et al (1994) p53 status and the efficacy of cancer therapy in vivo Science 266 807-10 PMID: 7973635 doi: 10.1126/science.7973635
12. Harris AL (1990) Mutant p53: the commonest genetic abnormality in human cancer [editorial] J Pathol 1625 6 PMID: 2231192 doi: 10.1002/path.1711620103

13. Nigro JM, Baker SJ, Preisinger AC et al (1989) Mutations in the p53 gene occur in diverse human tumour types Nature 342 705-8 PMID: 2531845 doi: 10.1038/342705a0

14. Baker SK, Fearon ER, Nigro JM et al (1989) Chromosome 17 deletions and p53 gene mutations in colorectal carcinoma Science 244 217-21 PMID: 2649981 doi: 10.1126/science. 2649981

15. Vogelstein B, Fearon ER, Hamilton MD et al (1988) Genetic alterations during colorectal tumour development $\boldsymbol{N}$ Engl J Med 319525 PMID: 2841597

16. Levine AJ, Momand $J$ and Finlay CA (1991) The p53 tumour suppressor gene Nature 351 453-6 PMID: $\underline{2046748}$ doi: $10.1038 / 351453 a 0$

17. Harris CC and Hollstein M (1993) Clinical implication of the p53 tumour suppressor gene N Engl J Med 329 1318-27 PMID: 8413413 doi: 10.1056/ NEJM199310283291807

18. Remvikos $Y$, Laurent-Puig $P$, Salmon RJ et al (1990) Simultaneous monitoring of p53 protein and DNA content of colorectal adenocarcinomas by flow cytometry Int J Cancer 45 450-6 PMID: 2137812 doi: 10.1002/ijc.2910450313

19. Borrensen-Dale A, Lothe RA, Meling GI, Hainut $P$, Rognum TO and Skovlund E (1998) TP53 and long-term prognosis in colorectal cancer: mutations in the L3 zinc-binding domain predict poor survival Clin Cancer Res 4 203-10 PMID: 9516972

20. Soussi T and Beroud C (2001) Assessing TP53 status in human tumours to evaluate clinical outcome Nat Rev Cancer 1 233-40 PMID: 11902578

21. Vidaurreta M, Maestro M L, Sanz-Casla MT et al (2008) Colorectal carcinoma prognosis can be predicted by alterations in gene p53 exons 5 and 8 Int $\mathbf{J}$ Colorectal Dis 23 581-6 PMID: 18322661 doi: 10.1007/s00384-0080454-8

22. Soong R, Powell B, Elsaleh $\mathrm{H}$ et al (2000) Prognostic significance of TP53 gene mutation in 995 cases of colorectal carcinoma: influence of tumour site, stage, adjuvant chemotherapy and type of mutation Eur $\mathbf{J}$ Cancer 36 2053-60 PMID: 11044641 doi: 10.1016/S09598049(00)00285-9

23. Blin N and Stafford DW (1976) A general method for isolation of high molecular weight DNA from eukaryotes Nucleic Acids Res 3 2303-8 PMID: 987581

24. Orita M, Iwahana $\mathrm{H}$, Kanazawa $\mathrm{H}$, Hayashi $\mathrm{K}$ and Sekiya $\mathrm{T}$ (1989) Detection of polymorphisms of human DNA by gel electrophoresis as single strand conformation 
polymorphism Proc Natl Acad Sci 86 2766-70 PMID: $\underline{2565038}$ doi: $10.1073 /$ pnas.86.8.2766

25. Bassam BJ, Caetano-Anolles G and Gresshoff PM (1995) Fast and sensitive silver staining DNA in polyacrylamide gels Anal Biochem 196 80-3 PMID 1716076 doi: 10.1016/0003-2697(91)90120-I

26. Bosari S, Marchetti A, Battita F et al (1995) Detection of p53 mutations by single strand conformation polymorphism (SSCP) gel electrophoresis, A comparative study of radioactive and non radioactive silver-stained SSCP analysis Diagn Mol Pathol 4249 55 PMID: 8634780 doi: 10.1097/00019606-19951200000004

27. West DW, Slattery ML, Robison LM et al (1989) Dietary intake and colon cancer: Sex and anatomic sitespecific associations $A \boldsymbol{A m}$ J Epidemiol $130 \quad 883-94$ PMID: 2554725

28. Cho Y, Gorina S, Jeffrey PD and Pavletich NP (1994) Crystal structure of a p53 tumour suppressor-DNA complex: understanding tumourigenic mutations Science 265 346-55 PMID: 8023157 doi: 10.1126/ science. 8023157

29. Kressner U, Inganas M, Byding, S, Blikstad I, Pahlman L, Glimelius B and Lindmark G (1999) Prognostic value of p53 genetic change in colorectal cancer $J$ Clin Oncol 17 593-99 PMID: 10080604

30. Tortola S, Marcuello E, Gonzalez I et al (1999) p53 and Kras gene mutations correlate with tumour aggressiveness but are not of routine prognostic value in colorectal cancer $\boldsymbol{J}$ Clin Oncol 17 1375-81 PMID: 10334521

31. Overgaard J, Yilmaz M, Guldberg $P$, Hansen LL and Overgaard J (2000) TP53 mutation is an independent prognostic marker for poor outcome in both nodenegative and node-positive breast cancer Acta Oncol 39 327-33 PMID: 10987229 doi: 10.1080/ 028418600750013096

32. Dix BR, Robbins $P$, Soong, $R$, Jenner $D$, House $A K$ and lacopetta BJ (1994) The common molecular genetic alterations in Dukes' B and C colorectal carcinomas are not short-term prognostic indicators of survival Int J Cancer 59 747-51 PMID: 7989112 doi: 10.1002/ijc. $\underline{2910590606}$
33. Hamelin R, Laurent-Puig $P$, Olschwang $S$ et al (1994) Association of p53 mutations with short survival in colorectal cancer Gastroenterology 106 42-8 PMID: $\underline{8276207}$

34. Goh H, Yao J and Smith DR (1995) p53 point mutation and survival in colorectal cancer patients Cancer Res 55 5217-22 PMID: 7585578

35. Bosari S, Viale G, Roncalli M et al (1995) p53 Gene mutations, p53 protein accumulation and compartmentalization in colorectal adenocarcinoma Am J Pathol 147 790-8 PMID: 7677190

36. Borresen-Dale A, Lothe RA, Meling GI, Hainaut $P$, Rognum TO and Skovlund E (1998) TP53 and long term prognosis in colorectal cancer: mutations in the L3 Zinc-binding domain predict poor survival Clin Cancer Res 4 203-10 PMID: 9516972

37. Servomaa K, Kiuru A, Kosma V-M, Hirvikoski $P$ and Rytömaa T (1998) p53 and K-ras gene mutations in carcinoma of the rectum among Finnish women $\mathrm{Mol}$ Pathol 53 24-30 PMID 10884918 doi: 10.1136/mp.53.1.24

38. Kumar R, Mende $P$, Tricker $A R$, Siddiqi $M$ and Preussmann $\mathrm{R}$ (1990) $\mathrm{N}$-nitroso compounds and their precursor in Brassica Oleracea Cancer Lett 54 61-5 PMID: 2208091 doi: 10.1016/0304-3835(90)90092-C

39. Rabes HM (1986) DNA adducts and cell cycle J Cancer Res Clin Oncol 58 4023-37

40. Pfeifer GP, Denissenko MF, Olivier M, Tretyakova N, Hecht SS and Hainaut $P$ (2002) Tobacco smoke carcinogens, DNA damage and p53 mutations in smoking associated cancers Oncogene 21 7435-51 PMID: 12379884 doi: 10.1038/sj.onc. 1205803

41. Russo A, Bazan V, lacopetta B, Kerr D, Soussi $T$ and Gebbia N (2005) The TP53 colorectal cancer international collaborative study on the prognostic and predictive significance of p53 mutation: Influence of tumor site, type of mutation, and adjuvant treatment $\mathbf{J}$ Clin Oncol 23 7518-28 PMID: 16172461 doi: 10.1200/ JCO.2005.00.471

42. Miyaki M, Lijima T, Ishii R, Kita $Y$, Koike M, Kuroki T and Mori T (2002) Increased frequency of p53 mutation in sporadic colorectal cancer from cigarette smokers Jpn J Clin Oncol 32196 PMID: 12110635 doi: 10.1093/jico/ hyf047 